\title{
Sistem Pendukung Keputusan Pemilihan Siswa Berprestasi Pada Aliyah Aras Kabu Agung Tanjungbalai Menggunakan Metode AHP
}

\author{
"Dahriansah , Andri Nata , Indra Ramadona Harahap \\ Program Studi Sistem Informasi, STMIK Royal Kisaran \\ Jl. Imam Bonjol No.179, Kisaran, Indonesia, 21222 \\ E-mail: andrinasution86@yahoo.com
}

\begin{abstract}
Abstrak
Penelitian ini bertujuan untuk merekomendasikan siswa berprestasi pada Aliyah Aras Kabu Tanjungbalai berdasarkan kriteria yang ditentukan dengan menggunakan teknik sistem pendukung keputusan.. Teknik pengambilan keputusan multi kriteria ini didasarkan pada teori bahwa setiap alternatif terdiri dari sejumlah kriteria yang memiliki nilai-nilai dan setiap kriteria memiliki bobot yang menggambarkan seberapa penting kriteria tersebut dengan kriteria lain. Hasil akhir yang diperoleh dari sistem pendukung keputusan ini akan memberikan suatu alternatif, untuk merekomendasikan siswa berprestasi pada Aliyah Aras Kabu Tanjungbalai. Adapun Nama siswa berprestasi pada Aliyah Aras Kabu Menurut Pehitungan Metode AHP Adalah Dari hasil perhitungan yang dilakukan oleh sistem, didapat bahwa ada 1 (satu) siswa yang bisa dijadikan rekomendasi dari 4 (empat) data penelitian yang dilakukan. Siswa tersebut berinisial A4 dengan nilai tertinggi 1,000
\end{abstract}

Kata Kunci: Sistem Pendukung Keputusan, Aliyah Aras Kabu, Siswa, Analytical Hierarchy Process

\begin{abstract}
This study aims to recommend high achieving students to Aliyah Aras Kabu Tanjungbalai based on criteria determined by using decision support system techniques. This multi-criteria decision making technique is based on the theory that each alternative consists of a number of criteria that have values and each criterion has a weight which illustrates how important these criteria are with other criteria. The final results obtained from this decision support system will provide an alternative, to recommend high achieving students to the Aliyah Aras Kabu Tanjungbalai. The name of the student's achievement in Aliyah Aras Kabu According to the AHP Method Calculation Is From the results of calculations performed by the system, it is found that there are 1 (one) students who can be made recommendations from 4 (four) research data conducted. The student initials A4 with the highest score of 1,000
\end{abstract}

Keywords: Decision Support System, Aliyah Aras Kabu, Students, Analytical Hierarchy Process 


\section{PENDAHULUAN}

Perkembangan teknologi informasi dan komunikasi, khususnya informasi berbasis komputer, yang awalnya hanya digunakan oleh kalangan tertentu, saat ini sudah sedemikian luas penggunaannya, hampir semua bidang teknologi informasi dan komunikasi misalnya informasi pendidikan, bisnis, ekonomi perbankan, sarana promosi, sarana sosial, dan lain sebagainya.

Pada sekolah untuk menentukan siswa dan mendapatkan siswa berprestasi yang sesuai dengan kriteria sangatlah penting. Kepala sekolah adalah orang yang memiliki kekuasaan dan bertanggung jawab untuk menentukan siswa yang mendapatkan siswa berprestasi dari sudut pandang netral dan membuat keputusan yang diterapkan oleh peraturan sebuah sekolah. Dalam melaksanakan pengelolahan data untuk memilih dan menyeleksi siswa yang mendapatkan siswa berprestasi masih menggunakan cara manual sehingga dalam pelaksanaannya dinilai kurang optimal. Demikian juga dalam memberikan penyeleksian kepada siswa dari seluruh kelas terkait sehingga tidak dapat dilakukan dengan maksimal.

Berdasarkan pada permasalahan diatas maka penulis menggunakan sistem pendukung keputusan dengan menggunakan metode AHP untuk menentukan siswa untuk siswa yang berprestasi. Sistem Pendukung Keputusan (Decision Support System) merupakan sistem informasi yang menyediakan informasi, permodelan dan pemanipulasian data. Sistem itu digunakan untuk membantu pengambilan keputusan dalam situasi yang semiterstruktur dan situasi yang tidak terstruktur, di mana tak seorang pun tahu secara pasti bagaimana keputusan seharusnya dibuat. Analitycal Hierarchy Process (AHP). Adalah metode untuk memecahkan suatu situasi yang komplek tidak terstruktur kedalam beberapa komponen dalam susunan yang hirarki, dengan memberi nilai subjektif tentang pentingnya setiap variabel secara relatif, dan menetapkan variabel mana yang memiliki prioritas paling tinggi guna mempengaruhi hasil pada situasi tersebut..

\section{METODE PENELITIAN}

1. Sistem Pendukung Keputusan

Sistem Pendukung Keputusan (SPK) merupakan sistem yang dapat memberikan pemecahan masalah, melakukan komunikasi untuk pemecahan masalah tertentu dengan terstruktur maupun tidak terstruktur. SPK didesain untuk dapat digunakan dan dioperasikan dengan mudah oleh orang yang hanya memiliki kemampuan dasar pengoperasian komputer. SPK dibuat dengan menerapkan adaptasi kompetensi yang tinggi sehingga dapat dijadikan sebagai alternatif dalam pengambilan sebuah keputusan[4]. SPK ditujukan untuk membantu pihak manajeman dalam menganalisis situasi yang kurang terstruktur dan dengan kriteria yang kurang jelas. SPK tidak dimaksudkan untuk mengotomatisasi pengambilan keputusan, tetapi memberikan perangkat interaktif yang memungkinkan pengambilan keputusan untuk melakukan berbagai analisis menggunakan model-model yang tersedia [5]..

\section{Metode Analytical Hierarchy Process (AHP)}

Analytical Hierarchy Process merupakan suatu metode pendukung keputusan yang dikembangkan oleh Thomas L. Saaty. Model pendukung keputusan ini akan menguraikan masalah multi faktor atau multi kriteria yang kompleks menjadi suatu hierarki. Menurut Saaty (1993), hierarki didefinisikan sebagai suatu representasi dari sebuah permasalahan yang kompleks dalam suatu struktur multilevel dimana level pertama adalah tujuan, yang diikuti level faktor, kriteria, sub kriteria, dan seterusnya hingga level terakhir dari alternative[1].

Konsistensi logis (Logical Consistency). Prinsip kerja AHP adala penyederhanaan suatu persoalan kompleks yang tidak terstruktur, stratejik, dan dinamik menjadi bagian- 
bagiannya, serta menata dalam suatu hierarki. Kemudian tingkat kepentingan setiap variabel diberi nilai numerik secara subjektif tentang arti penting variabel tersebut secara relatif dibandingkan dengan variabel lain. Dari berbagai pertimbangan tersebut kemudian dilakukan sintesa untuk menetapkan variabel yang memiliki prioritas tinggi dan berperan untuk mempengaruhi hasil pada sistem tersebut. Menurut Saaty (1993), terdapat tiga prinsip dalam memecahkan persoalan dengan AHP, yaitu prinsip menyusun hirarki (Decomposition), prinsip menentukan prioritas (Comparative Judgement), dan prinsip konsistensi logis (Logical Consistency). Metode "pairwise comparison" AHP mempunyai kemampuan untuk memecahkan masalah yang diteliti multi obyek dan multi kriteria yang berdasar pada perbandingan preferensi dari tiap elemen dalam hierarki. Jadi model ini merupakan model yang komperehensif. Pembuat keputusan menetukan pilihan atas pasangan perbandingan yang sederhana, membengun semua prioritas untuk urutan alternatif. "Pairwaise comparison" AHP mwenggunakan data yang ada bersifat kualitatif berdasarkan pada persepsi, pengalaman, intuisi sehigga dirasakan dan diamati, namun kelengkapan data numerik tidak menunjang untuk memodelkan secara kuantitatif.

Konsep dasar AHP adalah penggunaan matriks pairwise comparison (matriks perbandingan berpasangan) untuk menghasilkan bobot relative antar kriteria maupun alternative. Suatu kriteria akan dibandingkan dengan kriteria lainnya dalam hal seberapa penting terhadap pencapaian tujuan di atasnya. Penilaian dalam membandingkan antara satu kriteria dengan kriteria yang lain adalah bebas satu sama lain, dan hal ini dapat mengarah pada ketidak konsistensian. Saaty (1990) telah membuktikan bahwa indeks konsistensi dari matrik ber ordo $\mathrm{n}$ dapat diperoleh dengan rumus:

Dimana :

$$
\mathrm{Cl}=(\lambda \text { maks-n) } /(\mathrm{n}-1)
$$

$\mathrm{Cl}=$ Indeks Konsistensi (Consistency Index)

$\lambda$ maks $=$ Nilai eigen terbesar dari matrik berordo $n$

Nilai eigen terbesar didapat dengan menjumlahkan hasil perkalian jumlah kolom dengan eigen vector. Batas ketidak konsistensian di ukur dengan menggunakan rasio konsistensi (CR), yakni perbandingan indeks konsistensi $(\mathrm{Cl})$ dengan nilai pembangkit random $(\mathrm{RI})$. Nilai ini bergantung pada ordo matrik $\mathrm{n}$. Rasio konsistensi dapat dirumuskan :

$$
\mathrm{CR}=\mathrm{Cl} / \mathrm{RI}
$$

Bila nilai CR lebih kecil dari 10\%, ketidak konsistensian pendapat masih dianggap dapat diterima.

3. Fuzzy Associative Memory

Fuzzy Associative Memory (FAM) mengandung arti suatu model yang dilatih menggunakan jaringan syaraf, namun struktur jaringannya diinterpretasikan dengan sekelompok aturan-aturan fuzzy menurut Kasabov, 2002 (dalam Kusumadewi, 2010:297). Model arsitektur dari sistem FAM dapat dilihat seperti pada gambar berikut :

J-SISKO TECH Vol. 3, No. 1, $2020: 86-95$ 


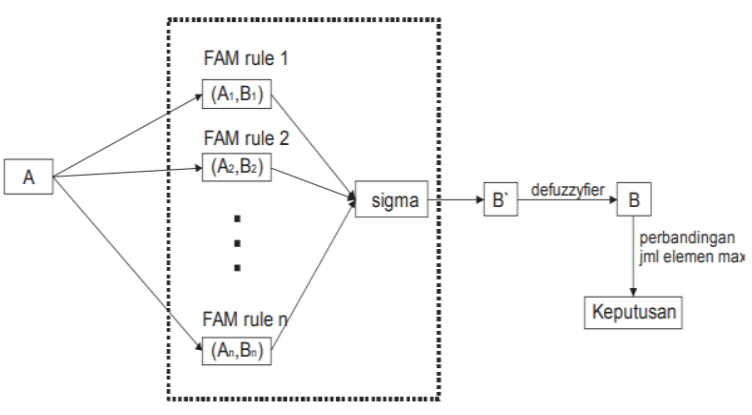

Gambar 1 Arsitektur FAM

Algoritma FAM adalah:

- Pembentukan fungsi keanggotaan

- Pembentukan matriks A dan B

- Pembentukan sistem FAM

- Melakuan perhitungan

III. ANALISIS DAN HASIL

Setelah data-data diinputkan (data kriteria dan data siswa berprestasi), maka dilakukan representasi ke dalam struktur hirarki. Permasalahan yang harus dirumuskan dalam membangun struktur hirarki adalah goal sebagai akhir keputusan. Goal menjadi keputusan terpenting dalam suatu kasus. Tujuan yang akan dicapai dalam tugas akhir ini adalah siswa berprestasi. Adapun identifikasi kriteria-kriteria pemilihan siswa berprestasi dapat diinisialkan menjadi simbol K (kriteria). Tahap identifikasi alternatif adalah mengidentifikasi siswa berprestasi yang menjadi objek penilaian dan goal nya siswa berprestasi. Pada penelitian ini, mengambil sample alternatif sebanyak 4.

Tabel 1 Alternatif Siswa berprestasi

\begin{tabular}{|c|c|c|c|}
\hline No & Alternatif & Nama Alternatif & Keterangan \\
\hline 1 & A1 & Dian Saputra & Juara Umum Kelas X \\
\hline 2 & A2 & Eka Syahfitri & Juara Umum Kelas XI \\
\hline 3 & A3 & Almunawarrah & Juara Umum IA XII \\
\hline 4 & A4 & Nura'ini & Juara Umum IS XII \\
\hline
\end{tabular}

Dengan kriteria sebagai berikut:

Tabel 2 Kriteria Siswa berprestasi

\begin{tabular}{|c|c|c|}
\hline No & Kriteria & Nama Kriteria \\
\hline 1 & K1 & Rata-rata Nilai Rapor \\
\hline 2 & K2 & Absensi \\
\hline 3 & K3 & Kedisiplinan \\
\hline 4 & K4 & Keikutsertaan Perlombaan \\
\hline
\end{tabular}

Sehingga struktur hirarki pada penjelasan studi kasus di atas dapat dilihat pada gambar berikut. 


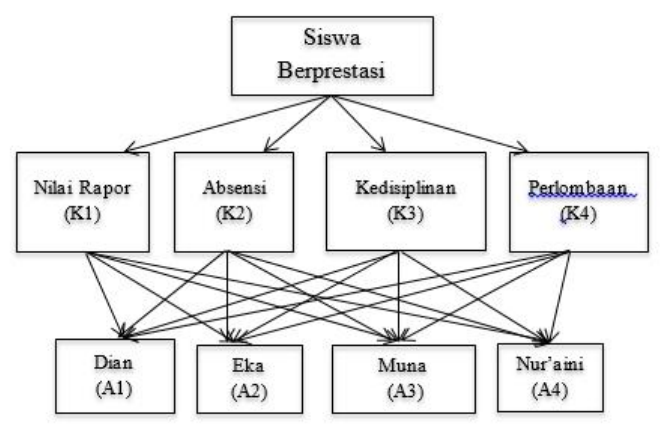

Gambar 2 Struktur Hirarki Pemilihan Siswa berprestasi

Menentukan nilai perbandingan matriks berpasangan dilakukan dengan metode AHP. Membandingkan input data antar kriteria dalam bentuk matriks berpasangan dengan menggunakan skala intensitas kepentingan AHP. Proses ini dilakukan untuk mengetahui nilai konsistensi rasio perbandingan (CR). Dimana syarat $\mathrm{CR}<0,1$. Dari nilai intensitas kepentingan kriteria dapat disimpulkan perbandingan antar tiap kriteria dalam tabel di bawah ini.

Tabel 3 Perbandingan Matriks Berpasangan Kriteria AHP

\begin{tabular}{|c|c|c|c|c|}
\hline Kriteria & $\mathrm{K} 1$ & $\mathrm{~K} 2$ & $\mathrm{~K} 3$ & $\mathrm{~K} 4$ \\
\hline $\mathrm{K} 1$ & 1,00 & 0,20 & 2,00 & 0,14 \\
\hline $\mathrm{K} 2$ & 5,00 & 1,00 & 6,00 & 0,33 \\
\hline $\mathrm{K} 3$ & 0,50 & 0,17 & 1,00 & 0,20 \\
\hline K4 & 7,00 & 3,00 & 5,00 & 1,00 \\
\hline Jumlah & 13,50 & 4,37 & 14,00 & 1,68 \\
\hline
\end{tabular}

Ada 4 kriteria pengambilan keputusan pada pemilihan siswa berprestasi, dan keempat empatnya harus dibandingkan dengan tiap siswa berprestasi dalam matriks berpasangan. Proses pencarían nilai prioritas siswa berprestasi setiap kriteria sama dengan proses pencarían nilai konsistensi kriteria. Menghitung nilai prioritas subkriteria dari kriteria.

\section{* Kriteria Rata-rata nilai rapor}

Tabel 4 Matriks Perbandingan Berpasangan Kriteria Rata-rata nilai rapor

\begin{tabular}{|c|c|c|c|c|}
\hline Altermatif & A1 & A2 & A3 & A4 \\
\hline A1 & 1,00 & 0,50 & 5,00 & 0,33 \\
\hline A2 & 2,00 & 1,00 & 7,00 & 0,50 \\
\hline A3 & 0,20 & 0,14 & 1,00 & 0,11 \\
\hline A4 & 3,00 & 2,00 & 9,00 & 1,00 \\
\hline Jumlah & 6,20 & 3,64 & 22,00 & 1,94 \\
\hline
\end{tabular}

Dari matriks perbandingan diatas, maka dapat dihitung nilai prioritas, lamda maksimum, dan CR. Sebelum menghitung nilai prioritas, dicari nilai perbandingan pada tiap kolom dibagi dengan jumlah kolomnya, seperti di bawah ini.

$\mathrm{A} 1=1 / 6,20=0,161$

$\mathrm{A} 2=0,50 / 3,64=0,137$

$A 3=5 / 22,00=0,227$

A4 $=0,33 / 1,94=0,171$, dan seterusnya untuk baris ke-2.

Tabel 5 Matriks Nilai Kriteria Rata-rata nilai rapor

\begin{tabular}{|c|c|c|c|c|}
\hline Alternatif & A1 & A2 & A3 & A4 \\
\hline A1 & 0,161 & 0,137 & 0,227 & 0,171 \\
\hline A2 & 0,323 & 0,275 & 0,318 & 0,257 \\
\hline A3 & 0,032 & 0,039 & 0,045 & 0,057 \\
\hline A4 & 0,484 & 0,549 & 0,409 & 0,514 \\
\hline Jumlah & $\mathbf{1 , 0 0 0}$ & $\mathbf{1 , 0 0 0}$ & $\mathbf{1 , 0 0 0}$ & $\mathbf{1 , 0 0 0}$ \\
\hline
\end{tabular}

J-SISKO TECH Vol. 3, No. 1, 2020: 86-95 
Setelah diperoleh hasil pembagian tiap kolomnya (tabel 4.10), maka dapat dihitung nilai prioritas, yaitu dengan menjumlahkan nilai-nilai dari setiap baris dan membaginya dengan banyak elemen alternatif untuk mendapatkan rata-rata. Untuk hasil penjumlahan nilai prioritas akan selalu bernilai satu.

Prioritas untuk alternatif $A 1=$

$$
\frac{0,161+0,137+0,227+0,171}{4}=0,174
$$

Prioritas untuk alternatif $A 2=$

$0,323+0,275+0,318+0,257$

$4 \quad=0,293$, dan seterusnya untuk alternatif selanjutnya, lihat pada table 4.11.

Tabel 6 Nilai Prioritas Kriteria Rata-rata nilai rapor

\begin{tabular}{|c|c|c|c|c|c|}
\hline Alternatif & A1 & A2 & A3 & A4 & prioritas \\
\hline A1 & 0,161 & 0,137 & 0,227 & 0,171 & 0,174 \\
\hline A2 & 0,323 & 0,275 & 0,318 & 0,257 & 0,293 \\
\hline A3 & 0,032 & 0,039 & 0,045 & 0,057 & 0,044 \\
\hline A4 & 0,484 & 0,549 & 0,409 & 0,514 & 0,489 \\
\hline Jumlah & $\mathbf{1 , 0 0 0}$ & $\mathbf{1 , 0 0 0}$ & $\mathbf{1 , 0 0 0}$ & $\mathbf{1 , 0 0 0}$ & $\mathbf{1 , 0 0 0}$ \\
\hline
\end{tabular}

- Membuat matriks penjumlahan tiap baris

Setelah diperoleh nilai prioritas kriteria rata-rata nilai rapor, maka dihitung nilai lamda maksimum ( $\lambda$ maks), yaitu dapat dihitung dengan mengalikan nilai prioritas pada tabel 6 dengan matriks perbandingan berpasangan (tabel 4.9). Hasil perhitungan disajikan dalam tabel 7.

Tabel 7 Matriks Penjumlahan

\begin{tabular}{|c|c|c|c|c|c|}
\hline Kriteria & K1 & K2 & K3 & K4 & Jumlah \\
\hline K1 & 0,174 & 0,147 & 0,218 & 0,163 & 0,701 \\
\hline K2 & 0,349 & 0,293 & 0,305 & 0,245 & 1,191 \\
\hline K3 & 0,035 & 0,042 & 0,044 & 0,054 & 0,175 \\
\hline K4 & 0,523 & 0,586 & 0,392 & 0,489 & 1,990 \\
\hline
\end{tabular}

Kolom jumlah pada tabel 4.12 diperoleh dengan menjumlahkan nilai pada masingmasing baris pada tabel tersebut. Misalnya, nilai 0,701 pada kolom jumlah merupakan hasil penjumlahan dari 0,174+0,147+0,218+0, 163 .

- Perhitungan Rasio Konsistensi

Penghitungan ini digunakan untuk memastikan bahwa nilai rasio konsistensi $(C R)<=$ 0.1. Jika ternyata nilai $C R$ lebih besar dari 0.1 , maka matriks perbandingan berpasangan harus diperbaiki. Untuk menghitung rasio konsistensi, dibuat tabel seperti terlihat dalam tabel 8.

Tabel 8 Matriks Rasio Konsistensi

\begin{tabular}{|c|c|c|c|}
\hline Kriteria & $\begin{array}{c}\text { Jumlah Tiap } \\
\text { Baris }\end{array}$ & Prioritas & Hasil \\
\hline K1 & 0,701 & 0,174 & 4,024 \\
\hline K2 & 1,191 & 0,293 & 4,063 \\
\hline K3 & 0,175 & 0,044 & 4,012 \\
\hline K4 & 1,990 & 0,489 & 4,069 \\
\hline \multicolumn{3}{|c|}{ Jumlah } & 16,168 \\
\hline
\end{tabular}

Kolom jumlah tiap baris diperoleh dari kolom jumlah pada tabel 4.12, sedangkan kolom prioritas diperoleh dari kolom prioritas pada tabel 4.11. kemudian kolom hasil diperoleh dari pembagian kolom jumlah tiap baris dengan klom prioritas. Dari tabel 4.13, diperoleh nilai-nilai sebagai berikut:

Jumlah (jumlahan dari nilai-nilai hasil) : 16,168

$\mathrm{n}$ (jumlah kriteria) : 4 
$\lambda$ maks $(16,168 / 4)=4,0420$

Dihitung nilai $\mathrm{Cl}$ dengan persamaan rumus $(\mathrm{Cl}=(\boldsymbol{\lambda}$ maks $-\mathbf{n}) / \mathbf{n}-\mathbf{1})$

$\mathrm{Cl}=\frac{4,0420-4}{4-1}=0,0140$

Setelah dapat nilai $\mathrm{Cl}$, kemudian hitung nilai $\mathrm{CR}$ dengan rumus $\mathrm{CR}=\mathrm{Cl} / \mathrm{IR}$. Nilai IR untuk $\mathrm{n}=4$ adalah 0,90 , sehingga

$\mathrm{CR}=\frac{0,0140}{0,90}=0,0156$ (Konsisten karena memenuhi syarat $\mathbf{C R}<\mathbf{0 , 1}$ )

Jika nilai $C R \geq 0.1$ maka tidak konsisten atau tidak memenuhi syarat dan diulang kembali matriks perbandingan hingga nilai CR nya memenuhi syarat yang telah ditentukan. Begitula selanjutnya cara menghitung untuk kriteria yang lainnya.

Langkah selanjutnya adalah membandingkan nilai prioritas masing-masing siswa berprestasi (alternatif) dengan nilai prioritas kriteria sehingga didapatkan prioritas tujuan masing-masing siswa berprestasi (alternatif) dengan rumus nilai prioritas masing-masing tiap siswa berprestasi (alternatif) .

Tabel 9 Nilai Prioritas Masing-Masing Siswa berprestasi Tiap Kriteria

\begin{tabular}{|c|c|c|c|c|}
\hline A $\mid$ K & K1 & K2 & K3 & K4 \\
\hline A1 & 0,174 & 0,511 & 0,212 & 0,048 \\
\hline A2 & 0,293 & 0,035 & 0,048 & 0,456 \\
\hline A3 & 0,044 & 0,173 & 0,422 & 0,132 \\
\hline A4 & 0,489 & 0,280 & 0,319 & 0,364 \\
\hline $\begin{array}{c}\text { Prioritas } \\
\text { Kriteria }\end{array}$ & $\mathbf{0 , 0 8 7}$ & $\mathbf{0 , 3 0 7}$ & $\mathbf{0 , 0 6 6}$ & $\mathbf{0 , 5 4 0}$ \\
\hline
\end{tabular}

Tabel 10 Nilai Prioritas Tujuan Masing-Masing Siswa berprestasi Tiap Kriteria

\begin{tabular}{|c|c|c|c|c|}
\hline AlK & K1 & K2 & K3 & K4 \\
\hline A1 & 0,174 & 0,511 & 0,212 & 0,048 \\
\hline A2 & 0,293 & 0,035 & 0,048 & 0,456 \\
\hline A3 & 0,044 & 0,173 & 0,422 & 0,132 \\
\hline A4 & 0,489 & 0,28 & 0,319 & 0,364 \\
\hline
\end{tabular}

Langkah terakhir adalah menghitung prioritas global dengan cara menjumlahkan baris pada Tabel 10, hasilnya dapat dilihat pada Tabel 11

Tabel 11 Nilai Prioritas Global Masing-Masing Siswa berprestasi

\begin{tabular}{|c|c|c|c|c|c|}
\hline AlK & K1 & K2 & K3 & K4 & $\begin{array}{c}\text { Prioritas } \\
\text { global }\end{array}$ \\
\hline A1 & 0,174 & 0,511 & 0,212 & 0,048 & $\mathbf{0 , 2 1 2}$ \\
\hline A2 & 0,293 & 0,035 & 0,048 & 0,456 & $\mathbf{0 , 2 8 6}$ \\
\hline A3 & 0,044 & 0,173 & 0,422 & 0,132 & $\mathbf{0 , 1 5 6}$ \\
\hline A4 & 0,489 & 0,28 & 0,319 & 0,364 & $\mathbf{0 , 3 4 6}$ \\
\hline
\end{tabular}

Berdasarkan nilai prioritas global dari tabel 4.31 diperoleh nilai tertinggi sebagai siswa berprestasi adalah alternatif A4 yaitu Nur'aini dengan nilai 0,346 menempati urutan 1.

\section{Form Login}

Pada form login ini user harus memasukkan nama dan password terlebih dahulu, kemudian klik tombol login.

J-SISKO TECH Vol. 3, No. 1, $2020: 86-95$ 


\section{Form Menu Utama}

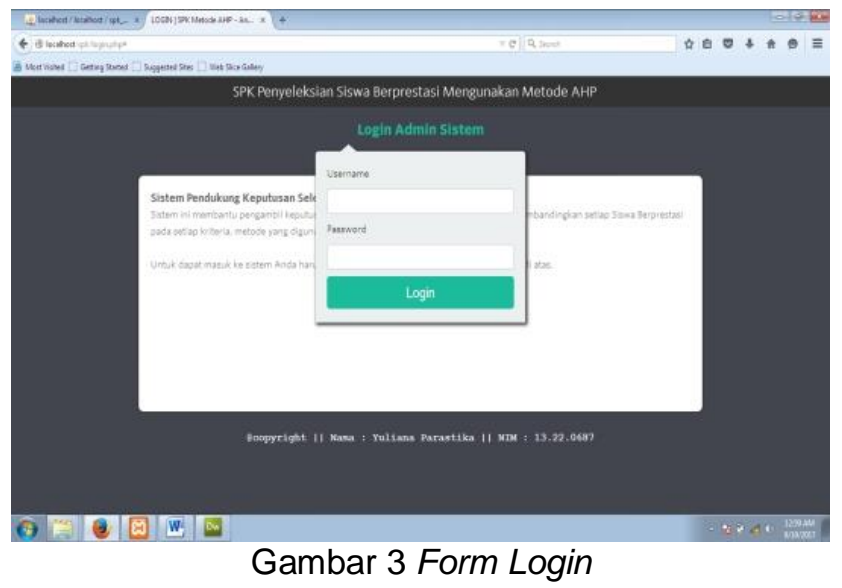

Form menu utama ini beerisikan menu-menu dan sub menu yang terdapat pada sistem admin yang telah dirancang sebelumnya, user dapat memilih menu-menu yang disediakan oleh sistem yang telah dibuat.

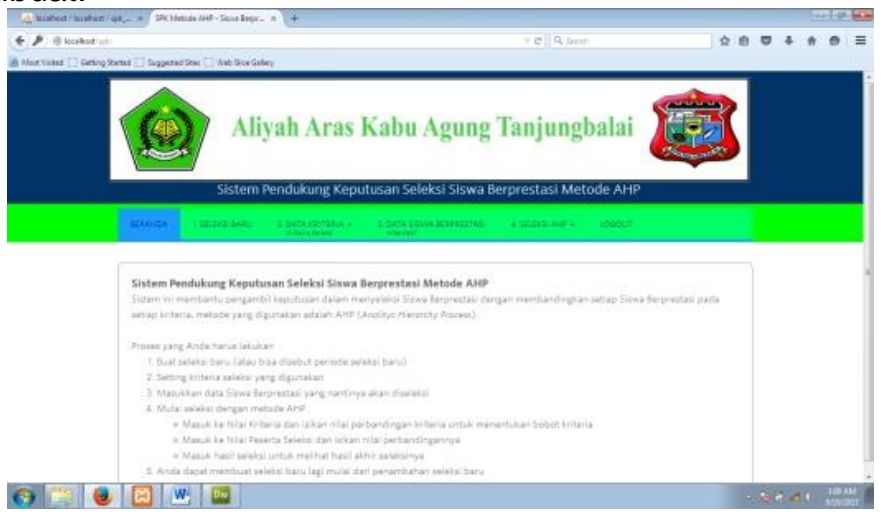

\section{Gambar 4 Form Menu Utama}

3. Form Data Alternatif Siswa Berprestasi

Form input data alternatif merupakan penginputan, pengeditan, pembatalan dan penghapusan data alternatif siswa berprestasi.
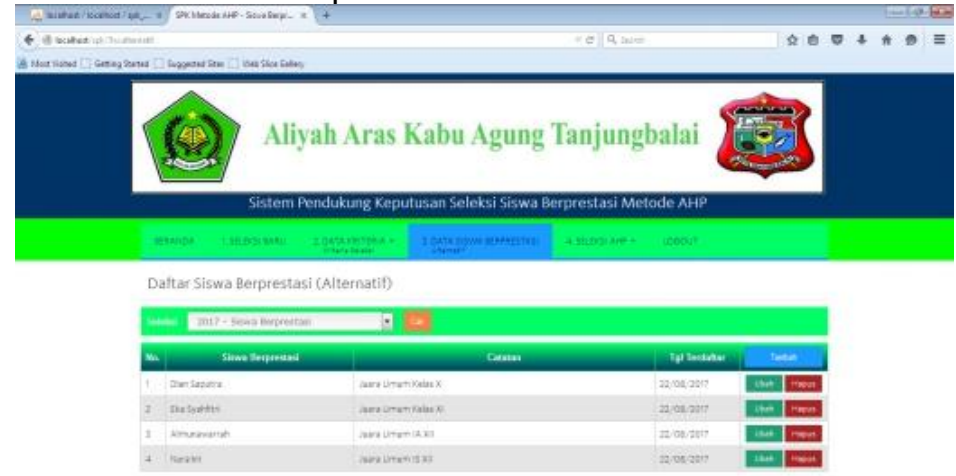

Gambar 5 Form Data Alternatif Siswa Berprestasi 
4. Form Data Kriteria

Form data Kriteria merupakan pengimputan, pengeditan, pembatalan dan penghapusan data Kriteria.

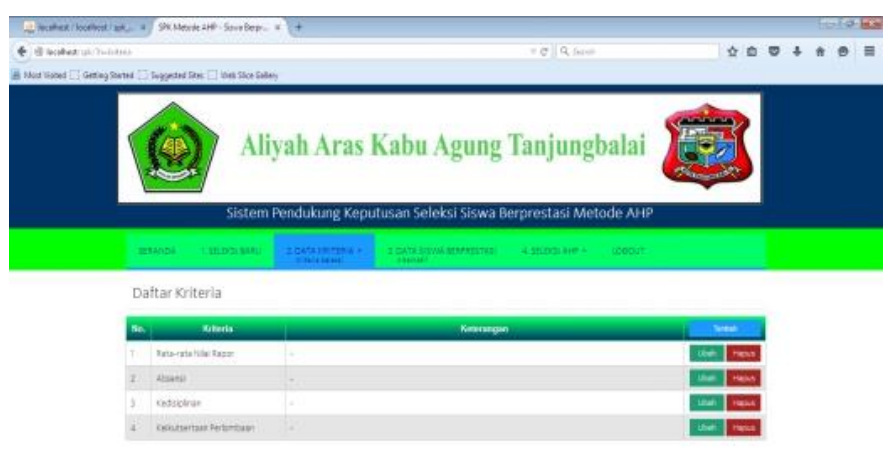

Gambar 6 Form Data Kriteria

5. Form Seleksi Baru

Form data seleksi baru merupakan penginputan, pengeditan, pembatalan dan penghapusan data seleksi.

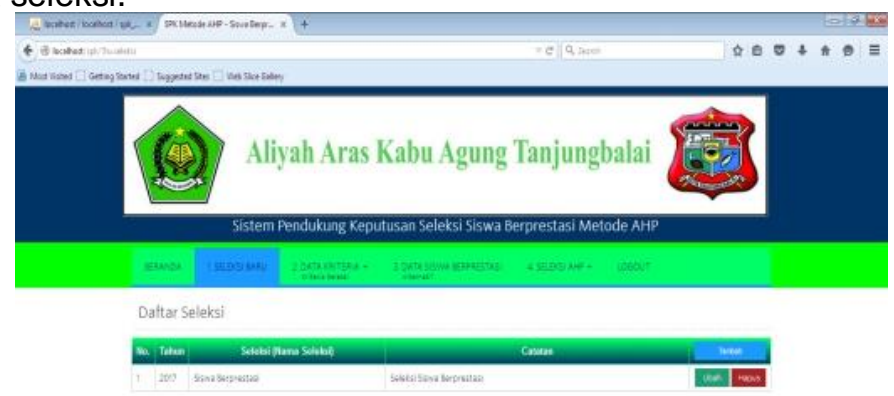

6. Form Hasil Seleksi

Form hasil seleksi merupakan pengimputan, pengeditan, pembatalan dan penghapusan hasil seleksi.

J-SISKO TECH Vol. 3, No. 1, $2020: 86-95$ 


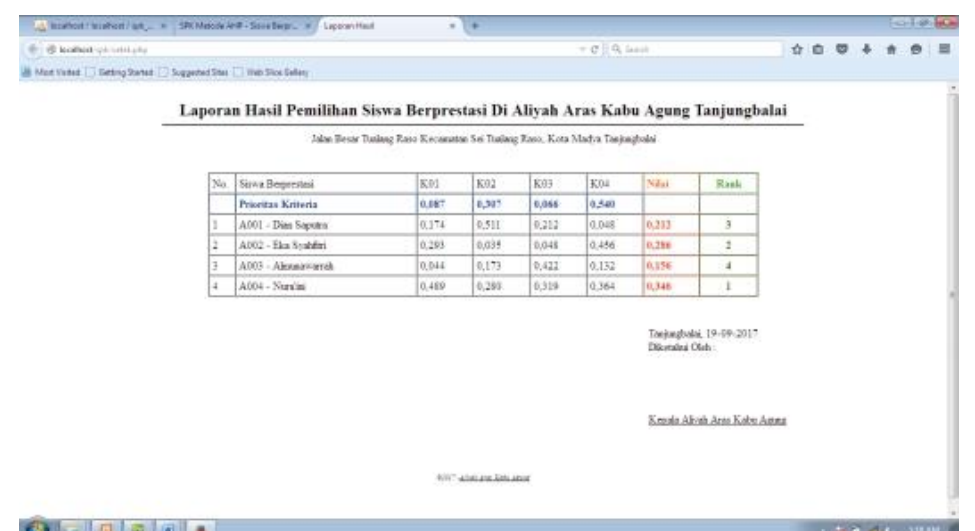

Gambar 8 Form Hasil Seleksi

Berdasarkan hasil implementasi sistem terhadap siswa berprestasi dapat dilihat bahwa hasil sesuai dengan perhitungan manual yang telah dilakukan dengan menggunakan metode AHP, Berdasarkan nilai dari sistem diperoleh nilai tertinggi sebagai siswa berprestasi adalah alternatif $A 4$ yaitu Nur'aini dengan nilai $\mathbf{0 , 3 4 6}$ menempati urutan 1.

\section{Kesimpulan}

Ada beberapa hal yang bisa dicermati pada sistem pendukung keputusan pemilihan siswa berprestasi Aliyah Aras Kabu Agung Tanjungbalai menggunakan metode AHP yaitu sebagai berikut:

1. Sistem pendukung keputusan pemilihan siswa berprestasi dapat membantu Aliyah Aras Kabu Agung Tanjungbalai dengan menggunakan metode AHP.

2. Membantu menyeleksi siswa berprestasi di Aliyah Aras Kabu Agung Tanjungbalai yang di pilih berdasarkan kriteria dan penilian alternatif.

3. Membantu Kepala Sekolah Aliyah Aras Kabu Agung Tanjungbalai untuk memilih siswa berprestasi.

4. Sistem ini dibuat dinamis sehingga jika ada perubahan atau penambahan terhadap penyeleksian siswa dapat dilakukan dengan mudah

\section{DAFTAR PUSTAKA}

[1] Agnia Eva Munthafa dan Husni, "Penerapan Metode Analytical Hierarchy Process Dalam Sistem Pendukung Keputusan Penentuan Mahasiswa Berprestasi” Jurnal Siliwangi Vol. 3. No. 2, 2017

[2] Aji Sasongko dkk, "Pemilihan Karyawan Baru Dengan Metode Ahp (Analytic Hierarchy Process)," Jurnal Informatika Mulawarman, Vol. 12, No. 2, 2017.

[3] Evan Rosiska, "Penerapan Metode Analitycal Hierarchy Process (AHP) dalam Menentukan Mitra Usaha Berprestasi”, Jurnal Resti, Vol.2 No. 2, 2018.

[4] Rusydi Umar dkk., "Sistem Pendukung Keputusan dengan Metode AHP untuk Penilaian Kompetensi Soft Skill Karyawan”, Jurnal Ilmu Komputer dan Informatika, Vol. 4, No. 1, 2018.

[5] Ernawati dkk, "Rancang Bangun Sistem Pendukung Keputusan Kenaikan Jabatan Pegawai Dengan Metode Profile Matching," Jurnal Sistem Informasi, 2017. 